\title{
Quality of Life and Health Status of Adults With Congenital Heart Disease in Vietnam: A Cross-sectional Study
}

\author{
Thanh Huong Truong \\ Hanoi Medical University \\ Ngoc Thanh Kim ( $\square$ kimngocthanh@hmu.edu.vn ) \\ Vietnam National Heart Institute https://orcid.org/0000-0002-1623-2530 \\ Mai Ngoc Thi Nguyen \\ National Heart Institute \\ Doan Loi Do \\ Vietnam National Heart Institute \\ Hong Thi Nguyen \\ Thanh Nhan Hospital \\ Thanh Tung Le \\ Vietnam National Heart Institute \\ Hong An Le \\ School of Medecine and Pharmacy: Vietnam National University
}

\section{Research}

Keywords: quality of life, health status, congenital heart disease, adults, Vietnam

Posted Date: January 15th, 2021

DOI: https://doi.org/10.21203/rs.3.rs-144267/v1

License: (c) (i) This work is licensed under a Creative Commons Attribution 4.0 International License. Read Full License 


\section{Abstract}

Background: Little is known about the quality of life (QOL) and health status of adults with congenital heart disease (CHD) in developing countries. Therefore, this study aimed to describe the QOL and health status of adults with CHD and investigate the association between QOL and biological and social characteristics of these patients in Vietnam.

Methods: A cross-sectional study was performed among 109 adults with CHD, hospitalised in the Vietnam National Heart Institute, between June 2019 and December 2019. Validated instruments to assess QOL and health status describing patient-reported outcomes were used, including the EuroQOL-5 Dimensions-5 Level, Satisfaction with Life Scale and Hospital Anxiety and Depression Scale. The data of QOL and health status were analysed using univariable and multivariable logistic regressions.

Results: The overall mean scores on the EuroQOL-descriptive system (EQ-DS) and the EuroQOL visual analogue scale (EQVAS) were $79.2(S D=12.2,95 \%$ confidence interval, $\mathrm{Cl}$ : 76.9-81.5) and $66.3(S D=12.5,95 \% \mathrm{Cl}: 63.9-68.7)$, respectively. Symptoms of anxiety and depression were common among adults with $\mathrm{CHD}(18.7 \%, \mathrm{n}=20$ and 11\%, $\mathrm{n}=12$; respectively). Stratified multivariate logistic regression revealed: poor QOL using the EQ-DS, and that anxiety related to suffering from a complex CHD or pulmonary artery hypertension (OR $=4.55 ; 95 \% \mathrm{Cl}: 1.26-16.4 ; \mathrm{p}=0.021$ and $\mathrm{OR}=4.19,95 \% \mathrm{Cl}$ : 1.2-14.56;

$\mathrm{p}=0.024$; respectively); poor QOL using the EQ-VAS and that anxiety and depression related to being unemployed or having an unstable employment $(\mathrm{OR}=4.16,95 \% \mathrm{Cl}: 1.64-10.56, \mathrm{p}=0.003 ; \mathrm{OR}=3.63,95 \% \mathrm{Cl}: 1.23-10.72, \mathrm{p}=0.02$ and $\mathrm{OR}=7.68$, 95\% Cl: 2.09-28.25, $\mathrm{p}=0.002$; respectively); and life dissatisfaction related to being unmarried $(\mathrm{OR}=4.63 ; 95 \% \mathrm{Cl}: 1.2-$ $17.86 ; p=0.026)$.

Conclusions: Adults with CHD in Vietnam experienced low QOL, and high levels of anxiety and depression. Poor QOL and psychological problems were related to being female, being unmarried, having low educational level, being unemployed or unstably employed, and having complex CHD or pulmonary artery hypertension.

\section{Background}

Congenital heart disease (CHD) is a common cardiac structural abnormality that affects one in 100 live births, globally. Many countries have made efforts towards improving the diagnostic quality and treatment of CHD, which has resulted in many children with CHD surviving well into adulthood (1-3). Several adults with CHD continually face physical and psychosocial difficulties and experience a declined quality of life (QOL) (4-6). Thereby, current guidelines on adults with $\mathrm{CHD}$ recommend comprehensive care to improve their QOL. This is useful for increasing integration opportunities in social activities and the daily lives of adults with CHD. In this context, knowledge of QOL in adults with CHD is an emerging domain and deserves investigation. However, in the long-term, many studies on QOL related to CHD have focused on children, adolescents, or their parent, despite the existence of a large gap in the knowledge regarding QOL and health status in adults with CHD, especially in developing countries $(4,7-17)$. The inconsistency of the QOL status of adults with $\mathrm{CHD}$ in developed countries and developing countries is concerning. Previous studies conducted in developed countries showed high QOL in adults with $\mathrm{CHD}(4,17,18)$. In contrast, the QOL of adults with CHD in developing countries seems poorer than the healthier population of the developing countries (13). Notably, according to the World Health Organization, a high QOL is the results of a good physical health status, normal psychological state, and positive social relationships. These items depend on medical intervention, healthcare systems, financial conditions of the concerned individual, the economic conditions of the nations and the sociocultural characteristics that differ among countries; for example, these characteristics may differ between Asian and European countries, low-/middle-income countries and high-income countries, developing and developed countries. Recently, an international study found that the effect of country specific characteristics of QOL score of adults with CHD has a great difference of 10.5 points between countries with the highest and lowest QOL $(15,19)$. From the abovementioned studies, we can conclude that it is essential to conduct research on 
QOL in adults with CHD in developing countries. This would be the base of implementation of important health and social policies to improve the QOL of adults with $\mathrm{CHD}$ in developing countries.

Vietnam is a densely-populated, dynamic country in Southeast Asia, with a population of 97 million; it can be classified as a low-/middle-income country. Apart from economic development, the Vietnamese government has also focused on improving the healthcare system. In fact, a previous study has highlighted the screening programs, diagnostic approaches, and treatment for patients with CHD throughout the country (20). Owing to these programs, many children have received timely intervention and have survived into adulthood. However, there is a gap for management for adults with CHD in Vietnam, including programs to improving their QOL. In this context, characteristics of Vietnamese patients might be generalised for adults with CHD in developing countries. In details, certain characteristics of adults with CHD include low level of education, unmarried status, unemployment, and unrepaired defects. However, we lack information about the assessed QOL in adults with CHD and its relationship with different sociodemographic characteristics in these countries. Therefore, the present study aimed to describe the QOL and health status of adults with CHD in Vietnam and investigate the association between the QOL and the biological and social characteristics of these patients.

\section{Methods}

\section{Study Design}

We performed a cross-sectional study at the Vietnam National Heart Institute, Bach Mai Hospital (Hanoi, Vietnam)-the largest hospital for adults with CHD in North Vietnam, and the national referral cardiovascular hospital, between June 2019 and December 2019. We recruited inpatients, who were admitted for cardiac imaging, intervention or surgery for CHD. All patients included in this study provided informed consent. Ethics approval was obtained from the Science Boards of the Department of Cardiology, Hanoi Medical University (no: 6655/QD-ĐHYHN).

\section{Inclusion criteria}

The inclusion criteria were: (1) individuals with structural CHD confirmed by cardiac imaging and (2) aged $\geq 16$ years. Transthoracic echocardiography was performed by experts on patients with CHD at Vietnam National Heart Institute during admission. If structural CHD on transthoracic echocardiography was doubted, we confirmed structural CHD by transoesophageal echocardiography, and/or cardiac computed tomography, and/or cardiac magnetic resonance imaging. In the study, we defined the age of attaining legal adulthood as 16 years, according to the Law on Children of Vietnam (http://vbpl.vn/TW/Pages/vbpqen-toanvan.aspx?ItemID=11044).

\section{Exclusion criteria}

Exclusion criteria for participants were: (1) other known cardiac diseases than CHD, (2) other known chronic diseases that require ongoing medical attention or limit activities of daily living, (3) known neuropathies, mental disorders, and syndromes affecting cognitive abilities, and (4) emotional fragility.

\section{Sample size}

$$
N=\frac{Z_{1-\alpha / 2}^{2} P(1-P)}{d^{2}}
$$

The sample size was calculated using the following formula in cross-sectional studies:

where $\mathrm{N}$ is the sample size, $\mathrm{Z}$ is the statistic corresponding to the confidence level, $\mathrm{P}$ is the expected prevalence and $\mathrm{d}$ is precision. The prevalence rate of reduced QOL in adults with CHD is $29.7 \%$ (15), and the prevalence rate of psychological problems in adults with $\mathrm{CHD}$ is $58.7 \%$ (21), with a $\mathrm{Cl}$ of $95 \%$, a precision of 0.1 , and a sample size of 94 . To prevent missing data, we added $15 \%$ to the sample size: the final sample size was 109. 


\section{Outcome measures}

The patients completed a survey that included items of biological and social characteristics such as age, sex, marital status, employment status, educational level, CHD type and CHD treatment. Subsequently, the following validated instruments describing patient-reported outcomes were completed to assess QOL and health status: EuroQOL-5 dimensions-5 level (EQ-5D-5L), Satisfaction with Life Scale (SWLS), Hospital Anxiety and Depression Scale (HADS). Additionally, face-to-face interviews were conducted by one well-trained nurse. This nurse answered and clarified the questions and doubts of patients during the survey. She also ensured that patients completed the survey independently.

Primary outcomes measures were self-reported QOL that was evaluated by EQ-5D-5L and SWLS, and self-reported psychosocial functioning that was evaluated by HADS. Secondary outcomes measures were socioeconomic status and the relationship between socioeconomic status and QOL and health status in adults with CHD.

\section{Vietnamese translation scales for QOL and health status}

The EQ-5D-5L is a questionnaire to assess health-related QOL and includes EQ-descriptive system (EQ-DS) and EQ visual analogue scale (EQ-VAS). Here, we referred to the previous Vietnamese translation EQ-5D-5L version that was developed taking into consideration the health preferences of the general adult population of Vietnam and validated elsewhere (22). EQ-DS defines health based on five dimensions: Mobility, Self-Care, Usual Activities, Pain/Discomfort, and Anxiety/Depression. Responses are rated on a 5-point Likert-type rating scale (no problems, slight problems, moderate problems, severe problems, and extreme problems). The value set for EQ-DS was redesigned for the Vietnamese population on a scale of 0 (worst imaginable QOL) to 100 (best imaginable QOL), while on the EQ-VAS, respondents rated the overall health of the day of the interview with scores ranging from 0 to 100, representing the worst and the best imaginable health state, respectively. Notably, poor QOL was defined by EQ-DS or EQ-VAS scores less than 65 (23).

The SWLS was a five-item instrument to measure general cognitive fundaments of life satisfaction. Each item is rated from 1 (strongly disagree) to 7 (strongly agree) for a total score of 5-35. A score of 20 represents a neutral point on the scale, while scores of $31-3526-30,21-25,15-19,10-14$ and 5-9 indicate that the respondent is extremely satisfied, satisfied, slightly satisfied, slightly dissatisfied, dissatisfied, and extremely dissatisfied with life, respectively (24). In our study, we referred to the Vietnamese translation version of the SWLS that was available (https://eddiener.com/scales/7).

The HADS comprises 14 items (graded as 0-3), which include seven items each for symptoms of anxiety (HADS-Anxiety subscale, HADS-A) and depression (HADS-Depression subscale, HADS-D). The total scores for depression and for anxiety range between 0 and 21 . We considered a score of 8-10 to represent borderline abnormality and 11-21 to represent symptoms of anxiety or depression (25). In this study, we referred to the Vietnamese translation version of the HADS, whose validity and reliability were confirmed in the previous studies with Cronbach's alpha as 0.80 for the HADS-D and 0.85 for the $\operatorname{HADS}-\mathrm{A}(26,27)$.

Following this, in our study, we modified the Vietnamese translation scales (EQ-5D-5L, SWLS, and HADS) above. Some Vietnamese words were retranslated to make questions and options more understandable for interviewees. The process of modifying the Vietnamese translation scales included three stages. In stage one, the EQ-5D-5L, SWLS and HADS were independently translated from English into Vietnamese by three professionals fluent in English: one cardiologist, one fifth year student and one translator who had a medical background. In stage two, a medical expert compared all versions of the translations produced in the previous steps with the available translated version and agreed on the pre-final version. Finally, in stage three, our research team, consisting of all the members conducting in this study, discussed the pre-final version, reached consensus and produced the final Vietnamese translation versions of the EQ-5D-5L, SWLS and HADS (Supplement 1).

\section{Statistical Analysis}


Data were analysed by SPSS v22 (IBM Inc., Armonk, NY, USA). Normally-distributed continuous variables are described as mean (standard deviation [SD], 95\% confidence interval [CI]) and non-normally distributed continuous variables are described as median and interquartile range (IQR). Nominal variables are presented as absolute numbers $(n)$ and percentages. Frequencies and percentages were calculated for nominal variables. Differences in normally distributed continuous variables were assessed using the Student's $t$-test, and differences in non-normally distributed variables were assessed using the Mann-Whitney $U$ tests. Comparisons of nominal variables between subgroups were performed by Chisquare tests or Fisher's exact tests. The univariable and multivariable forward logistic regression model using the forward stepwise method (likelihood ratio) was performed to evaluate the associations between biological-social characteristics and poor QOL and health status of the participants. In all analyses, a two-tailed p-value below 0.05 was considered statistically significant.

\section{Results}

\section{Patient characteristics}

A total of 109 adults with CHD were enrolled in this study. The patients were predominantly women $(n=76,69.7 \%)$. The participants' overall mean age was 37.8 years $(S D=12.7,95 \% \mathrm{Cl}$ : 35.4-40.2); the mean age of the male and female patients was 33.7 years $(S D=13.4,95 \% \mathrm{Cl}: 29.0-38.5)$ and $39.6(S D=12.0,95 \% \mathrm{Cl}: 36.9-42.3)$ years, respectively. A majority of patients $(n=70,64.2 \%)$ were older than 30 years. The characteristics of patients are summarized in Table 1. In addition, many patients had an education level of less than high school ( $n=49,45 \%)$; were unmarried (never married, widowed, divorced, separated; $n=30,27.5 \%)$; were unemployed or had unstable employment $(n=27,24.8 \%)$; and had complex CHD or pulmonary artery hypertension $(n=16,14.7 \%)$. Notably, most patients had unrepaired CHD $(n=81,74.3 \%)$, or repaired palliation $(n=5,4.6 \%)$.

\section{Characteristics of quality of life}

The overall mean EQ-DS and EQ-VAS were $79.2(S D=12.2,95 \% \mathrm{Cl}: 76.9-81.5)$ and $66.3(S D=12.5,95 \% \mathrm{Cl}: 63.9-68.7)$, respectively. The overall mean EQ-DS was significantly higher than EQ-VAS $(p<0.001$, Student $t$-test). A significant number of adults with CHD had poor QOL (EQ-DS < 65, $n=13,11.9 \%$; EQ-VAS < 65, $n=45,41.3 \%$ ). Table 2 summarises in details the distribution of EQ-5D-5L scale. Additionally, the most common problems reported were pain/discomfort $(n=95,87.2 \%)$ followed by anxiety/depression $(n=83,76.1 \%)$, mobility problems $(n=46,42.2 \%)$, and problems with usual activities $(n=$ $41,37.6 \%)$, whereas the least reported complaint was regarding self-care $(n=11,10.1 \%)$.

\section{Characteristics of health status}

The overall mean SWLS was $25.2 \pm 4.3$ (95\% Cl 24.3-25.9). Specifically, 3.7\% participants were dissatisfied, 5.5\% were slightly dissatisfied, $2.8 \%$ reported neural, $42.2 \%$ were slightly satisfied, $36.7 \%$ satisfied and $9.2 \%$ extremely satisfied. According to the HADS, the overall mean score for anxiety was $6.9(S D=4.4,95 \% \mathrm{Cl}: 6.1-7.8)$, and the overall mean score for depression was $5.9(S D=3.8,95 \% \mathrm{Cl}: 5.2-6.6)$. The anxiety component revealed that $18.7 \%(\mathrm{n}=20)$ patients experienced significant anxiety. Symptoms of depression were common; $11 \%(n=12)$ of patients displayed significant symptoms of depression.

\section{Association between quality of life, health status and biological-social characteristics in adults with congenital heart disease}

As shown in Table 3, significant differences exist among the EQ-DS subgroups that were classified according to age, education level, employment status. The mean EQ-DS was lower in patients aged $>30$ years compared with patients aged $\leq 30$ years (76.4 [SD $=12.5$ ], $95 \% \mathrm{Cl}: 73.4-79.4$ vs 84.1 [SD $=9.7$ ], $95 \% \mathrm{Cl}: 81.0-87.3, \mathrm{p}=0.001$ in overall; 76.6 [SD = 11.1], 95\% Cl: 70.4-82.7 vs 85.3 [SD = 8.6], 95\% Cl: 81.0-89.6, p = 0.016 in men; 76.4 [SD = 13.0], 95\% Cl: $72.9-79.9$ vs 83.1 [10 
.6], $95 \% \mathrm{Cl}: 78.2-87.9, \mathrm{p}=0.039$ in women, using the Student $t$-test). The mean EQ-DS was lower in patients who had an education level less than high school compared to patients who had education level of high school and more (75.4 [SD = 13.0], $95 \% \mathrm{Cl}: 71.6-79.1$ vs 82.7 [SD $=10.4$ ], $95 \% \mathrm{Cl}: 80.0-85.5, \mathrm{p}=0.002$ in overall; 74.6 [SD = 13.2], $95 \% \mathrm{Cl}$ : $65.2-84.1$ vs 86.3 [SD = 6.1], 95\% Cl: 83.5-89.1, p = 0.002 in men, using Student $t$-test). The mean EQ-DS was lower in unemployed patients or patients with unstable employment compared to employed patients (75.4 [SD $=13.6$ ], $95 \%$ Cl: $70.0-80.8$ vs 80.7 [SD $=11.4$ ], $95 \% \mathrm{Cl}: 78.2-83.3, \mathrm{p}=0.049$ in overall; 73.7 [SD $=15.1$ ], $95 \% \mathrm{Cl}: 59.8-87.7$ vs 84.8 [SD $=7.1$ ], $95 \% \mathrm{Cl}: 81.7-$ 87.8, $\mathrm{p}=0.01$ in men, using the Student $t$-test). Moreover, the mean EQ-DS in employed women was 79.0 (SD $=12.5,95 \%$ Cl: 75.6-82.3) and lower than employed men as $84.8(S D=7.1,95 \% \mathrm{Cl}: 81.7-87.8)$ with $\mathrm{p}=0.037$, using Student $t$-test.

As shown in Table 4, there existed significant differences of the mean EQ-VAS between subgroups that were classified according to age, education level, employment status, and CHD type. The mean EQ-VAS was lower in patients aged $>30$ years comparing with patients aged $\leq 30$ years $(64.3$ [SD = 13.1], 95\% Cl: $61.2-67.4$ vs 69.9 [SD = 10.8], 95\% Cl: 66.4-73.4, $p=0.024$ in overall; 60.7 [SD $=12.1$ ], $95 \%$ Cl: $53.6-67.8$ vs 72.2 [SD $=10.2$ ], $95 \%$ Cl: $67.0-77.1, p=0.008$ in men, using the Student $t$-test). The mean EQ-VAS was lower in patients who had an education level less than high school, compared to patients who had education level as high school and more (63.2 [SD = 11.9], 95\% Cl: 59.7-66.6 vs 69.5 [SD = 12.0], 95\% Cl: $66.3-72.7, p=0.008$ in overall; 61.0 [SD = 13.7], 95\% Cl: $51.2-70.8$ vs 71.9 [SD $=9.1$ ], 95\% Cl: $67.6-76.1, p=0.015$ in men, using the Student $t$-test). The mean EQ-VAS was lower in unemployed patients or patients with unstable employment comparing with employed patients $(61.3$ [SD $=10.0$ ], $95 \% \mathrm{Cl}: 57.4-65.2$ vs 68.4 [SD $=12.5], 95 \% \mathrm{Cl}, 65.6-71.2, p=0.009$ in overall; 58.6 [SD = 13.5], 95\% Cl: 46.1-71.1 vs 71.1 [SD = 9.6], 95\% Cl: $67.1-75.2, \mathrm{p}=0.009$ in men, using Student $t$-test). The mean EQ-VAS was lower in complex CHD or pulmonary artery hypertension patients compared to simple CHD patients (60.0 [SD = 14.1], $95 \%$ Cl: $52.5-67.5$ vs 67.4 [SD = 12.0], 95\% Cl: $64.9-69.9, \mathrm{p}=0.029$ in overall; 56.0 [SD = 11.4], $95 \% \mathrm{Cl}$ : $41.8-70.2$ vs 68.8 [SD $=12.0$ ], $95 \% \mathrm{Cl}: 64.2-73.5, \mathrm{p}=0.034$ in men, using the Student $t$-test). Moreover, the mean EQ-DS in unmarried women was $58.5(\mathrm{SD}=16.9,95 \% \mathrm{Cl}$ : 48.3-68.7), which was lower than married women as $67.6(\mathrm{SD}=11.0,95 \%$ Cl: 64.8-70.4) with $\mathrm{p}=0.016$, using the Student $t$-test.

Figure 1 shows prevalence of poor QOL by subgroups, in adults with CHD. Notably, the prevalence of poor QOL that was defined as EQ-DS $<65$ in complex CHD or pulmonary artery disease patients was higher than those in simple CHD patients (31.3\%, $n=5$ vs $8.6 \%, n=8, p=0.01$, using the Chi-square test). While the prevalence of poor QOL that was defined as EQVAS $<65$ in patients aged $>30$ years, was higher than patients aged $\leq 30$ years $(50 \%, n=35$ vs $25.6 \%, n=10, p=0.013$, using the Chi-square test), prevalence of poor QOL that was defined as EQ-VAS $<65$ in patients who had an education level less than high school, and higher than patients who had an education level as high school and more $(55.1 \%, n=27$ vs $28.6 \%, n=16, p=0.006$, using Chi-square test) and prevalence of poor QOL that was defined as EQ-VAS $<65$ in unemployed patients or patients with unstable employment, was higher than that of employed patients $(66.7 \%, n=18$ vs $37.6 \%, n=35, p=0.001$, using Chi-square test).

Figure 2 shows prevalence of dissatisfaction by subgroups in adults with CHD. Notably, the prevalence of dissatisfaction in unmarried patients was higher married patients $(20 \%, n=6$ vs $5.1 \%, n=4, p=0.016$, using the Fisher's exact test).

Figure 3 shows prevalence of anxiety and depression by subgroups in adults with CHD. Notably, prevalence of anxiety in unemployed patients or patients who had unstable employment was higher than that of employed patients ( $34.6 \%, n=9$ vs $14.1 \%, n=11, p=0.022$, using Chi-square test) and prevalence of depression in unemployed patients or patients who had unstable employment was higher than that of employed patients $(29.6 \%, n=8$ vs $5.1 \%, n=4, p=0.002$, using the Fisher's exact test). Prevalence of anxiety in complex CHD or pulmonary artery hypertension patients was higher than that of simple patients ( $40 \%, n=6$ vs $15.2 \%, n=14, p=0.022$, using Chi-square test). Prevalence of depression in married patients was higher than that of unmarried patients $(17.1 \%, n=12$ vs $0 \%, n=0, p=0.004$, using Fisher's exact test). Prevalence of depression in patients who had an education level less than high school was higher patients who had education level as high school and more $(22.4 \%, \mathrm{n}=0.001$ vs $1.8 \%, \mathrm{n}=1, \mathrm{p}=0.001$, using the Fisher's exact test). 
The result of stratified univariable and multivariable logistic regressions in the prediction of poor QOL and health status are summarized in Table 5. Using multivariable logistic regression, poor QOL (EQ-DS < 65) was associated with being a patient with a complex CHD or pulmonary artery disease (OR $=4.55 ; 95 \% \mathrm{Cl}: 1.26-16.4 ; \mathrm{p}=0.021)$. Poor QOL $(E Q-V A S<65)$ was associated with being unemployed or having an unstable employment $(\mathrm{OR}=4.16 ; 95 \% \mathrm{Cl}: 1.64-10.56 ; \mathrm{p}=0.003)$. Dissatisfaction was associated with being unmarried $(\mathrm{OR}=4.63 ; 95 \% \mathrm{Cl}: 1.2-17.86 ; \mathrm{p}=0.026)$. Anxiety was associated with being unemployed or an unstable employment $(\mathrm{OR}=3.63 ; 95 \% \mathrm{Cl}: 1.23-10.72 ; \mathrm{p}=0.02)$, and having a complex $\mathrm{CHD}$ or pulmonary hypertension ( $\mathrm{OR}=4.19 ; 95 \% \mathrm{Cl}: 1.2-14.56, \mathrm{p}=0.024)$. Depression was associated with being unemployed or having an unstable employment $(\mathrm{OR}=7.68 ; 95 \% \mathrm{Cl}: 2.09-28.25 ; \mathrm{p}=0.002)$.

\section{Discussion}

To the best of our knowledge, this study is the first of its kind providing evidence regarding QOL and health status in adults with CHD, in Vietnam; it contributes essential knowledge on these matters in Vietnam. There was a significant number of adults with $\mathrm{CHD}$ reporting poor QOL, anxiety, and depression. Notably, we found that poor QOL and psychological problems were well-related to biological and social characteristics including gender, age, marital status, education level, employment status, and CHD type.

\section{Quality of life characteristics}

Our findings demonstrated that the majority of adults with CHD in Vietnam had poor QOL measure by EQ-5D-5L. The participants of our study showed lower mean EQ-DS and EQ-VAS scores compared to healthy individuals from a general population study in Vietnam (28). Overall, poor QOL are common in adults with CHD, similar to the findings from previous studies in Iran (13). A previous systematic review and meta-analysis that enrolled 18 studies from developed countries found that QOL in young adults with CHD was comparable or better compared with health controls (4). This result might be explained by the differences in economic factors, educational status, cultural factors, and medical quality between developing and developed countries (15). Indeed, we found that adults with CHD had greater problems with pain/discomfort, anxiety/depression, mobility, and usual activities, which is similar to the results of a previous study (29). $\mathrm{CHD}$ is a chronic condition; if it is underdiagnosed or undertreated, it can result in reduced QOL and may even be life threatening (4). Furthermore, in our study, the mean EQ-VAS score was significantly lower than the mean EQ-DS score; only $2.7 \%$ of patients had EQ-VAS $\geq 80$, while $50.4 \%$ of patients had EQ-5D $\geq 80$. EQ-VAS is more appropriate than EQ-DS in measuring the global health ratings (28). Therefore, EQ-VAS is a more valid, reliable, and responsive tool for measuring the health status in adults with CHD.

\section{Satisfaction with life}

Satisfaction with life was common in adults with CHD in Vietnam (90.2\%) with a high mean score of satisfaction of 25.2 points. This score appears to be more resilient than the report from Iran (13) but it was similar to that of 15 countries in APPROACH-IS (15). Consistent with Vietnamese adults with other complex diseases as spinal cord injury (30), our patients with CHD also trend positive cognitive judgments about their life. Reality, satisfaction with life of one individual was influenced by specific country variables such as economic status, cultural factors, and social characteristics. Level of life satisfaction was more strongly associated with financial satisfaction in low- and middle-income countries than in highincome countries (31). Likewise, satisfaction with life of individuals in Asian countries was strongly affected by a society's national integration (32). It explained the trending satisfaction with life in patients living in a country with dynamic economy and culture of Asia as typical as that of Vietnam.

\section{Anxiety and depression of adults with congenital heart disease}

We noted the high prevalence of symptoms of anxiety and depression in adults with CHD. The prevalence of self-reported anxiety among adults with CHD are more than seven times higher compared to the general population in Vietnam (18.7\%

Page $7 / 23$ 
vs. 2.6\%), while the prevalence of self-reported depression among adults with CHD is more than seven times higher compared to the general population in Vietnam (11\% vs 2.8\%) (33). Our findings were similar to that of a recent study, which reported that $30.7 \%$ of adults with $\mathrm{CHD}$ had mood disorders and $28 \%$ had anxiety disorders (21). However, the exact prevalence of psychological disturbances, their geographical differences, and valid scales of evaluations are lacking. Based on the literature, adults with CHD constitute a high-risk group for developing emotional problems related to reduced exercise capacity, complications, and social barriers $(5,21,34-37)$. Therefore, screening for mental disorders in adults with CHD is important for early diagnosis and appropriate treatment because they require special medical attention and psychosocial interventions (38).

Notably, worrying causes patients to take positive or negative actions regarding the heart disease. At adequate levels, worrying is useful in promoting health protective behaviours and adherence to treatment. However, high levels of stress can adversely affect health outcomes (39). Furthermore, patients with high levels of anxiety have been reported to have fewer healthy coping strategies with stressful situations, increased chance of adopting behaviours, and non-adherence to treatment (40).

\section{Effect of biological and social characteristics to quality of life and health status}

Similar to findings of previous studies, we observed that women with CHD tended to have reduced QOL scores and increased risks of psychological problems than men $(14,29,36,41)$. Indeed, differences of QOL and psychological problems between women and men were also found in general Vietnamese population $(28,42)$ and in other countries $(43$, 44). This may be related to a tendency of sensitivity to social environment, worrying about the vulnerability to diseases in women as compared with men (45).

The effect of older age on QOL in CHD is not consistent. Certain research found lower QOL in older patients compared to young patients but others noted increased or unchanged QOL (11). The prior study has found that older age plays a limited role in predicting poor QOL, anxiety and depression in adults with CHD (46). In the current study, in logistic repression, age > 30 years was not the predictor of poor QOL and mental problems. Notably, we also found lower QOL scores in older patients compared to young patients than the general Vietnamese populations (28).

Multivariable logistic repression showed that the likelihood of depression in unmarried adults with CHD is about five times greater as compared to married adults with CHD. EQ-VAS in unmarried women was significantly lower compared to married women. With reference to previous studies, we noted that a reduced QOL, anxiety and depression was more common in unmarried individuals than married individuals. This might be related to the disadvantages of psychological distress, socioeconomic and psychosocial resources that appear frequently in unmarried individuals compared to married individuals, especially in women $(43,47)$. For example, married individuals often share financial expenses and receive sympathy from spouses while unmarried individuals do not have such support.

In this study, educational level was associated with QOL and health status. Prevalence of poor QOL, anxiety, and depression in patients with less than high school education was approximately two times higher than patients with high school education and more. Although studies regarding educational level in adults with CHD in developing countries are limited, previous studies in developed countries have reported similar results between education level and QOL and mental disorders $(14,41,48)$.

Our results also indicated that patients who were unemployed or had unstable employment had a four-fold to seven-fold increased risk of poor QOL, anxiety, and depression; this is consistent with the results of previous study on adults with CHD (41). Generally, unemployment or unstable employment have negative effects on self-assessed health $(49,50)$. We believe that the impact of unemployment or unstable employment on poor QOL results from declined financial consequences, reduced self-esteem, and barriers in social relationships. Therefore, patients with $\mathrm{CHD}$ should be provided with stable 
employment, which may help them cope with their illness, encourage them to overcome the psychological barriers, and improve their social relationships and QOL.

Furthermore, we observed the negative effect of complex CHD or pulmonary hypertension on patients with simple CHD. Previous studies have reported a negative association between regular physical activity and anxiety $(51,52)$. Exercise and physical activity are useful to gain self-confidence. Exercise and physical activity are also good opportunities to meet or socialize with others that improve mood and help to cope in a healthy way. However, exercise intolerance was common in patients with complex CHD and pulmonary hypertension (53).

\section{Limitations}

This study had a few limitations. First, this was a cross-sectional, single-location study. Although, this study was taken at the reference hospital in Vietnam, there still exists sampling bias about representativeness. Using patient self-report results in certain biases since certain responses could be exaggerated or under-reported. Besides, because of the small sample, it was difficult to analyze and compare between subgroups, which was important to investigate the association between QOL and biological and social characteristics of the patients in Vietnam.

\section{Conclusions}

To the best of our knowledge, our study provides the first evidence on reduced QOL, anxiety and depression, in Vietnamese adults with CHD. The findings highlight that an increased prevalence of low QOL and psychological problems in the following subgroups: women, older age, unmarried, lower education level, unemployment, and, complex CHD or pulmonary artery hypertension. Therefore, we recommend that health-related QOL should be screened more often, and monitored in clinical practice for adults with CHD, especially for high-risk patients.

\section{Abbreviations}

CHD: Congenital Heart Disease

Cl: Confidence Intervals

EQ-5D-5L: EuroQOL-5 Dimensions-5 Level

EQ-DS: EuroQOL-Descriptive System

EQ-VAS: EuroQOL Visual Analogue Scale

HADS: Hospital Anxiety and Depression Scale

HADS-A: Hospital Anxiety and Depression Scale-Anxiety subscale

HADS-D: Hospital Anxiety and Depression Scale-Depression subscale

OR: Odds Ratios

QOL: Quality of Life

SWLS: Satisfaction with Life Scale

\section{Declarations}


The study was approved by the Council for Science, Department of Cardiology, Hanoi Medical University (no: 6655/QDDHYHN) of Vietnam. All participants provided written informed consent after receiving clear explanation of the study objective and procedures. Participants were allowed to withdraw from the interview at any time. All personal information was kept confidential and only anonymous data were utilized for the study.

\section{Consent for publication}

All participants provided their consent for publication.

\section{Availability of data and materials}

The datasets used and/or analysed in the current study will be made available by the corresponding author upon reasonable request.

\section{Competing interests}

The authors have no competing interests to declare.

\section{Funding}

No funding for provided for this study.

\section{Authors' contributions}

THT and NTK conceived the study, designed the data collection tools, monitored the data collection, analysed the data, and drafted and revised the paper. MNTN, DLD, HTN, TTL and HAL monitored data collection, analysed the data, and revised the draft of the study. All authors read and approved the final manuscript.

\section{Acknowledgements}

We are grateful to the medics and nurses from Bach Mai Hospital, residents and medical students at the Hanoi Medical University for their support in this study.

\section{Author details}

Assoc. Prof Thanh-Huong Truong, MD, PhD: Former Heads of Department of Congenital Heart Disease and Paediatric Cardiology, Vietnam National Heart Institute, Bach Mai Hospital; Senior Lecturer of Department of Cardiology, Hanoi Medical University.

\section{References}

1. Moons P, Bovijn L, Budts W, Belmans A, Gewillig M. Temporal trends in survival to adulthood among patients born with congenital heart disease from 1970 to 1992 in Belgium. Circulation. 2010;122(22):2264-72.

2. Zimmerman MS, Smith AGC, Sable CA, Echko MM, Wilner LB, Olsen HE, et al. Global, regional, and national burden of congenital heart disease, 1990 - 2017: a systematic analysis for the Global Burden of Disease Study 2017. The Lancet Child \& Adolescent Health. 2020;4(3):185-200.

3. van der Linde D, Konings EE, Slager MA, Witsenburg M, Helbing WA, Takkenberg JJ, et al. Birth prevalence of congenital heart disease worldwide: a systematic review and meta-analysis. Journal of the American College of Cardiology. 2011;58(21):2241-7.

4. Fteropoulli T, Stygall J, Cullen S, Deanfield J, Newman SP. Quality of life of adult congenital heart disease patients: a systematic review of the literature. Cardiology in the young. 2013;23(4):473-85. 
5. Eslami B, Sundin O, Macassa G, Khankeh HR, Soares JJ. Anxiety, depressive and somatic symptoms in adults with congenital heart disease. Journal of psychosomatic research. 2013;74(1):49-56.

6. Benderly M, Kalter-Leibovici O, Weitzman D, Blieden L, Buber J, Dadashev A, et al. Depression and anxiety are associated with high health care utilization and mortality among adults with congenital heart disease. International journal of cardiology. 2019;276:81-6.

7. Bratt EL, Moons P. Forty years of quality-of-life research in congenital heart disease: Temporal trends in conceptual and methodological rigor. International journal of cardiology. 2015;195:1-6.

8. Moon JR, Huh J, Song J, Kang IS, Park SW, Chang S-A, et al. The Center for Epidemiologic Studies Depression Scale is an adequate screening instrument for depression and anxiety disorder in adults with congential heart disease. Health and Quality of Life Outcomes. 2017;15(1):176.

9. Khoshhal S, Al-Harbi K, Al-Mozainy I, Al-Ghamdi S, Aselan A, Allugmani M, et al. Assessment of quality of life among parents of children with congenital heart disease using WHOQOL-BREF: a cross-sectional study from Northwest Saudi Arabia. Health and Quality of Life Outcomes. 2019;17(1):183.

10. Teixeira FM, Coelho RM, Proença C, Silva AM, Vieira D, Vaz C, et al. Quality of life experienced by adolescents and young adults with congenital heart disease. Pediatric cardiology. 2011;32(8):1132-8.

11. Apers S, Luyckx K, Moons P. Quality of life in adult congenital heart disease: what do we already know and what do we still need to know? Current cardiology reports. 2013;15(10):407.

12. van Rijen EH, Utens EM, Roos-Hesselink JW, Meijboom FJ, van Domburg RT, Roelandt JR, et al. Psychosocial functioning of the adult with congenital heart disease: a 20-33 years follow-up. Eur Heart J. 2003;24(7):673-83.

13. Eslami B, Macassa G, Sundin Ö, Khankeh HR, Soares JJ. Quality of life and life satisfaction among adults with and without congenital heart disease in a developing country. European journal of preventive cardiology. 2015;22(2):16979.

14. Chen CA, Liao SC, Wang JK, Chang Cl, Chiu IS, Chen YS, et al. Quality of life in adults with congenital heart disease: biopsychosocial determinants and sex-related differences. Heart (British Cardiac Society). 2011;97(1):38-43.

15. Apers S, Kovacs AH, Luyckx K, Thomet C, Budts W, Enomoto J, et al. Quality of Life of Adults With Congenital Heart Disease in 15 Countries: Evaluating Country-Specific Characteristics. Journal of the American College of Cardiology. 2016;67(19):2237-45.

16. Moons P, Luyckx K. Quality-of-life research in adult patients with congenital heart disease: current status and the way forward. Acta Paediatrica. 2019;108(10):1765-72.

17. Schrøder M, Boisen KA, Reimers J, Teilmann G, Brok J. Quality of life in adolescents and young adults with CHD is not reduced: a systematic review and meta-analysis. Cardiology in the young. 2016;26(3):415-25.

18. Eaton SL, Wang Q, Menahem S. Determinants of quality of life in adults with CHD: an Australian cohort. Cardiology in the young. 2017;27(8):1571-6.

19. Apers S, Kovacs AH, Luyckx K, Alday L, Berghammer M, Budts W, et al. Assessment of Patterns of Patient-Reported Outcomes in Adults with Congenital Heart disease - International Study (APPROACH-IS): rationale, design, and methods. International journal of cardiology. 2015;179:334-42.

20. Phuc VM, Tin DN, Giang DTC. Challenges in the management of congenital heart disease in Vietnam: A single center experience. Ann Pediatr Cardiol. 2015;8(1):44-6.

21. Westhoff-Bleck M, Briest J, Fraccarollo D, Hilfiker-Kleiner D, Winter L, Maske U, et al. Mental disorders in adults with congenital heart disease: Unmet needs and impact on quality of life. Journal of affective disorders. 2016;204:180-6.

22. Mai VQ, Sun S, Minh HV, Luo N, Giang KB, Lindholm L, et al. An EQ-5D-5L Value Set for Vietnam. Quality of Life Research2020. p. 1923-33.

23. Barton GR, Sach TH, Avery AJ, Jenkinson C, Doherty M, Whynes DK, et al. A comparison of the performance of the EQ5D and SF-6D for individuals aged >or= 45 years. Health economics. 2008;17(7):815-32.

Page $11 / 23$ 
24. Diener E, Emmons RA, Larsen RJ, Griffin S. The Satisfaction With Life Scale. Journal of Personality Assessment. 1985;49(1):71-5.

25. Zigmond AS, Snaith RP. The hospital anxiety and depression scale. Acta psychiatrica Scandinavica. 1983;67(6):36170.

26. Do TTH, Correa-Velez I, Dunne MP. Trauma Exposure and Mental Health Problems Among Adults in Central Vietnam: A Randomized Cross-Sectional Survey. Front Psychiatry. 2019;10:31-.

27. Truong DV, Bui QTT, Nguyen DT, Moore J. Anxiety Among Inpatients With Cancer: Findings From a Hospital-Based Cross-Sectional Study in Vietnam. Cancer Control. 2019;26(1):1073274819864641.

28. Nguyen LH, Tran BX, Hoang Le QN, Tran TT, Latkin CA. Quality of life profile of general Vietnamese population using EQ-5D-5L. Health and Quality of Life Outcomes. 2017;15(1):199.

29. Berghammer M, Karlsson J, Ekman I, Eriksson P, Dellborg M. Self-reported health status (EQ-5D) in adults with congenital heart disease. International journal of cardiology. 2013;165(3):537-43.

30. Tasiemski T, Priebe MM, Wilski M. Life satisfaction and life values in people with spinal cord injury living in three Asian countries: a multicultural study. J Spinal Cord Med. 2013;36(2):118-26.

31. Oishi S, Diener EF, Lucas RE, Suh EM. Cross-Cultural Variations in Predictors of Life Satisfaction: Perspectives from Needs and Values. Personality and Social Psychology Bulletin. 1999;25(8):980-90.

32. Jagodzinski W. Economic, Social, and Cultural Determinants of Life Satisfaction: Are there Differences Between Asia and Europe? Social Indicators Research. 2010;97(1):85-104.

33. Vuong DA, Van Ginneken E, Morris J, Ha ST, Busse R. Mental health in Vietnam: Burden of disease and availability of services. Asian Journal of Psychiatry. 2011;4(1):65-70.

34. Eslami B. Correlates of posttraumatic stress disorder in adults with congenital heart disease. Congenital heart disease. 2017;12(3):357-63.

35. Jackson JL, Misiti B, Bridge JA, Daniels CJ, Vannatta K. Emotional functioning of adolescents and adults with congenital heart disease: a meta-analysis. Congenital heart disease. 2015;10(1):2-12.

36. Kovacs AH, Saidi AS, Kuhl EA, Sears SF, Silversides C, Harrison JL, et al. Depression and anxiety in adult congenital heart disease: predictors and prevalence. International journal of cardiology. 2009;137(2):158-64.

37. Bang JS, Jo S, Kim GB, Kwon BS, Bae EJ, Noh Cl, et al. The mental health and quality of life of adult patients with congenital heart disease. International journal of cardiology. 2013;170(1):49-53.

38. Diller G-P, Bräutigam A, Kempny A, Uebing A, Alonso-Gonzalez R, Swan L, et al. Depression requiring anti-depressant drug therapy in adult congenital heart disease: prevalence, risk factors, and prognostic value. European Heart Journal. 2015;37(9):771-82.

39. Bremner JD, Campanella C, Khan Z, Shah M, Hammadah M, Wilmot K, et al. Brain Correlates of Mental Stress-Induced Myocardial Ischemia. Psychosomatic medicine. 2018;80(6):515-25.

40. Abed MA, Kloub MI, Moser DK. Anxiety and adverse health outcomes among cardiac patients: a biobehavioral model. The Journal of cardiovascular nursing. 2014;29(4):354-63.

41. Vigl M, Niggemeyer E, Hager A, Schwedler G, Kropf S, Bauer U. The importance of socio-demographic factors for the quality of life of adults with congenital heart disease. Quality of life research : an international journal of quality of life aspects of treatment, care and rehabilitation. 2011;20(2):169-77.

42. Nguyen T, Tran T, Tran H, Tran T, Fisher J. The burden of clinically significant symptoms of common and severe mental disorders among adults in Vietnam: a population-based cross-sectional survey. BMC Public Health. 2019;19(1):1173.

43. Han KT, Park EC, Kim JH, Kim SJ, Park S. Is marital status associated with quality of life? Health Qual Life Outcomes. 2014;12:109. 
44. Campos ACV, e Ferreira EF, Vargas AMD, Albala C. Aging, Gender and Quality of Life (AGEQOL) study: factors associated with good quality of life in older Brazilian community-dwelling adults. Health and Quality of Life Outcomes. 2014;12(1):166.

45. McLean CP, Asnaani A, Litz BT, Hofmann SG. Gender differences in anxiety disorders: prevalence, course of illness, comorbidity and burden of illness. J Psychiatr Res. 2011;45(8):1027-35.

46. Moons P, Kovacs AH, Luyckx K, Thomet C, Budts W, Enomoto J, et al. Patient-reported outcomes in adults with congenital heart disease: Inter-country variation, standard of living and healthcare system factors. International journal of cardiology. 2018;251:34-41.

47. Bierman A, Fazio EM, Milkie MA. A Multifaceted Approach to the Mental Health Advantage of the Married:Assessing How Explanations Vary by Outcome Measure and Unmarried Group. Journal of Family Issues. 2006;27(4):554-82.

48. Pfitzer C, Helm PC, Rosenthal LM, Walker C, Ferentzi H, Bauer UMM, et al. Educational level and employment status in adults with congenital heart disease. Cardiology in the young. 2018;28(1):32-8.

49. McKee-Ryan F, Song Z, Wanberg CR, Kinicki AJ. Psychological and physical well-being during unemployment: a metaanalytic study. The Journal of applied psychology. 2005;90(1):53-76.

50. Norström F, Virtanen P, Hammarström A, Gustafsson PE, Janlert U. How does unemployment affect self-assessed health? A systematic review focusing on subgroup effects. BMC public health. 2014;14:1310-.

51. Sareen J, Cox BJ, Clara I, Asmundson GJ. The relationship between anxiety disorders and physical disorders in the U.S. National Comorbidity Survey. Depression and anxiety. 2005;21(4):193-202.

52. Goodwin RD. Association between physical activity and mental disorders among adults in the United States. Preventive medicine. 2003;36(6):698-703.

53. Diller G-P, Dimopoulos K, Okonko D, Li W, Babu-Narayan SV, Broberg CS, et al. Exercise Intolerance in Adult Congenital Heart Disease. Circulation. 2005;112(6):828-35.

\section{Tables}

Table 1 Demographic characteristics of adults with congenital heart disease 


\begin{tabular}{|c|c|}
\hline Characteristics & $\mathbf{N}(\%)$ \\
\hline \multicolumn{2}{|l|}{ Gender } \\
\hline Men & $33(30.3)$ \\
\hline Women & $76(69.7)$ \\
\hline \multicolumn{2}{|l|}{ Age groups } \\
\hline $16-30$ & $39(35.8)$ \\
\hline $31-40$ & $31(28.4)$ \\
\hline $41-50$ & $18(16.5)$ \\
\hline $51-60$ & $14(12.8)$ \\
\hline $61+$ & $7(6.4)$ \\
\hline \multicolumn{2}{|l|}{ Marital status } \\
\hline Never married & $23(21.1)$ \\
\hline Married/cohabiting & $79(72.5)$ \\
\hline Window or divorce or separate & $7(6.4)$ \\
\hline \multicolumn{2}{|l|}{ Education level } \\
\hline Secondary school and less & $49(45.0)$ \\
\hline High school & $19(17.4)$ \\
\hline Undergraduate and postgraduate & $37(33.9)$ \\
\hline Missing data & $4(3.7)$ \\
\hline \multicolumn{2}{|l|}{ Occupation } \\
\hline Farmer & $30(27.5)$ \\
\hline Blue-collar & $22(20.2)$ \\
\hline White-collar & $30(27.5)$ \\
\hline Student & $6(5.5)$ \\
\hline Others & $21(19.3)$ \\
\hline \multicolumn{2}{|l|}{ Employment status } \\
\hline Stable & $59(54.1)$ \\
\hline Homemaker or retired & $14(12.8)$ \\
\hline Unstable & $21(19.3)$ \\
\hline Unemployed & $6(5.5)$ \\
\hline Student or other work & $6(5.5)$ \\
\hline Missing data & $3(2.8)$ \\
\hline
\end{tabular}

Page 14/23 


\begin{tabular}{|ll|}
\hline Type of congenital heart disease & \\
\hline Isolated atrial septal defect & $53(48.6)$ \\
\hline Isolated ventricular septal defect & $29(26.6)$ \\
\hline Isolated patent ductus arteriosus & $19(17.4)$ \\
\hline Combined ventricular septal defect and patent ductus arteriosus & $1(0.9)$ \\
\hline Combined atrial septal defect and pulmonary stenosis & $1(0.9)$ \\
\hline Combined ventricular septal defect and pulmonary stenosis & $2(1.8)$ \\
\hline Tetralogy of Fallot & $3(2.8)$ \\
\hline Pulmonary atresia with ventricular septal defect & $1(0.9)$ \\
\hline Congenital heart disease status & \\
\hline Simple & $93(85.3)$ \\
\hline Complex or pulmonary artery hypertension & $16(14.7)$ \\
\hline Treatment for congenital heart disease & $81(74.3)$ \\
\hline Interventional/surgical correction & $23(21.1)$ \\
\hline Interventional/surgical palliation & $5(4.6)$ \\
\hline Unrepaired & \\
\hline
\end{tabular}

Table 2 Profiles of EQ-5D-5L in adults with congenital heart disease 


\begin{tabular}{|c|c|c|c|c|c|c|c|c|c|c|c|}
\hline \multirow[t]{2}{*}{ Scales } & & \multicolumn{10}{|c|}{ Score range } \\
\hline & & $0-10$ & $11-20$ & $21-30$ & $31-40$ & $41-50$ & $51-60$ & $\begin{array}{l}61- \\
70\end{array}$ & $\begin{array}{l}71- \\
80\end{array}$ & $\begin{array}{l}81- \\
90\end{array}$ & $\begin{array}{l}91- \\
100\end{array}$ \\
\hline \multirow[t]{2}{*}{$E Q-D S$} & $N$ & 0 & 0 & 0 & 0 & 4 & 3 & 16 & 31 & 30 & 25 \\
\hline & $\%$ & 0 & 0 & 0 & 0 & 3.7 & 2.8 & 14.7 & 28.4 & 27.5 & 22.9 \\
\hline \multirow[t]{2}{*}{$E Q-V A S$} & $N$ & 0 & 1 & 0 & 4 & 13 & 27 & 36 & 25 & 2 & 1 \\
\hline & $\%$ & 0 & 0.9 & 0 & 3.7 & 11.9 & 24.8 & 33 & 22.9 & 1.8 & 0.9 \\
\hline \multirow[t]{2}{*}{ Domains of EQ-DS } & & \multicolumn{10}{|c|}{ Levels } \\
\hline & & \multicolumn{2}{|c|}{$\begin{array}{l}\text { Extreme } \\
\text { problems }\end{array}$} & \multicolumn{2}{|c|}{$\begin{array}{l}\text { Severe } \\
\text { problems }\end{array}$} & \multicolumn{2}{|c|}{$\begin{array}{l}\text { Moderate } \\
\text { problems }\end{array}$} & \multicolumn{2}{|c|}{$\begin{array}{l}\text { Slight } \\
\text { problems }\end{array}$} & \multicolumn{2}{|c|}{ No problems } \\
\hline \multirow[t]{2}{*}{ Mobility } & $N$ & \multicolumn{2}{|l|}{0} & \multicolumn{2}{|l|}{0} & \multicolumn{2}{|l|}{6} & \multicolumn{2}{|l|}{40} & \multicolumn{2}{|l|}{63} \\
\hline & $\%$ & \multicolumn{2}{|l|}{$0 \%$} & \multicolumn{2}{|l|}{$0 \%$} & \multicolumn{2}{|l|}{$5.5 \%$} & \multicolumn{2}{|c|}{$36.7 \%$} & \multicolumn{2}{|c|}{$57.8 \%$} \\
\hline \multirow[t]{2}{*}{ Self-care } & $N$ & \multicolumn{2}{|l|}{0} & \multicolumn{2}{|l|}{0} & \multicolumn{2}{|l|}{0} & \multicolumn{2}{|l|}{11} & \multicolumn{2}{|l|}{98} \\
\hline & $\%$ & \multicolumn{2}{|l|}{$0 \%$} & \multicolumn{2}{|l|}{$0 \%$} & \multicolumn{2}{|l|}{$0 \%$} & \multicolumn{2}{|c|}{$10.1 \%$} & \multicolumn{2}{|c|}{$89.9 \%$} \\
\hline \multirow[t]{2}{*}{ Usual activities } & $N$ & 0 & & 0 & & 4 & & 37 & & 68 & \\
\hline & $\%$ & $0 \%$ & & $0 \%$ & & $3.7 \%$ & & $33.9 \%$ & & $62.4 \%$ & \\
\hline Pain/Discomfort & $N$ & 0 & & 1 & & 17 & & 77 & & 14 & \\
\hline & $\%$ & $0 \%$ & & $0.9 \%$ & & $15.6 \%$ & & $70.6 \%$ & & $12.8 \%$ & \\
\hline Anxiety/Depression & $N$ & 1 & & 5 & & 16 & & 61 & & 26 & \\
\hline & $\%$ & $0.9 \%$ & & $4.6 \%$ & & $14.7 \%$ & & $56 \%$ & & $23.9 \%$ & \\
\hline
\end{tabular}

Table 3 EQ-DS utility scores by subgroups in adults with congenital heart disease 


\begin{tabular}{|c|c|c|c|c|c|c|c|c|c|c|}
\hline & \multicolumn{3}{|l|}{ Total } & \multicolumn{3}{|c|}{ Men (1) } & \multicolumn{3}{|c|}{ Women (2) } & \multirow{2}{*}{$\begin{array}{l}p- \\
\text { value* }\end{array}$} \\
\hline & $\begin{array}{l}\text { Mean } \\
(S D)\end{array}$ & $95 \% \mathrm{Cl}$ & $\begin{array}{l}p- \\
\text { value }\end{array}$ & $\begin{array}{l}\text { Mean } \\
(S D)\end{array}$ & $95 \% \mathrm{Cl}$ & $\begin{array}{l}p- \\
\text { value }\end{array}$ & $\begin{array}{l}\text { Mean } \\
(S D)\end{array}$ & $95 \% \mathrm{Cl}$ & $\begin{array}{l}p- \\
\text { value }\end{array}$ & \\
\hline Total & $\begin{array}{l}79.2 \\
(12.1)\end{array}$ & $\begin{array}{l}76.9- \\
81.5\end{array}$ & & $\begin{array}{l}81.4 \\
(10.6)\end{array}$ & $\begin{array}{l}77.6- \\
85.1\end{array}$ & & $\begin{array}{l}78.2 \\
(12.7)\end{array}$ & $\begin{array}{l}75.3- \\
81.1\end{array}$ & & 0.22 \\
\hline \multicolumn{11}{|l|}{ Age groups } \\
\hline $16-30$ & $\begin{array}{l}84.1 \\
(9.7)\end{array}$ & $\begin{array}{l}81.0- \\
87.3\end{array}$ & \multirow[t]{2}{*}{0.001} & $\begin{array}{l}85.3 \\
(8.6)\end{array}$ & $\begin{array}{l}81.0- \\
89.6\end{array}$ & \multirow[t]{2}{*}{0.016} & $\begin{array}{l}83.1 \\
(10.6)\end{array}$ & $\begin{array}{l}78.2- \\
87.9\end{array}$ & \multirow[t]{2}{*}{0.039} & 0.472 \\
\hline $31+$ & $\begin{array}{l}76.4 \\
(12.5)\end{array}$ & $\begin{array}{l}73.4- \\
79.4\end{array}$ & & $\begin{array}{l}76.6 \\
(11.1)\end{array}$ & $\begin{array}{l}70.4- \\
82.7\end{array}$ & & $\begin{array}{l}76.4 \\
(13.0)\end{array}$ & $\begin{array}{l}72.9- \\
79.9\end{array}$ & & 0.964 \\
\hline \multicolumn{11}{|l|}{ Marital status } \\
\hline Married & $\begin{array}{l}79.5 \\
(10.8)\end{array}$ & $\begin{array}{l}77.1- \\
81.9\end{array}$ & \multirow[t]{2}{*}{0.659} & $\begin{array}{l}79.5 \\
(10.6)\end{array}$ & $\begin{array}{l}73.9- \\
85.1\end{array}$ & \multirow[t]{2}{*}{0.339} & $\begin{array}{l}79.5 \\
(11.0)\end{array}$ & $\begin{array}{l}76.7- \\
82.3\end{array}$ & \multirow[t]{2}{*}{0.056} & 0.999 \\
\hline Unmarried & $\begin{array}{l}78.3 \\
(15.2)\end{array}$ & $\begin{array}{l}72.7- \\
84.0\end{array}$ & & $\begin{array}{l}83.1 \\
(10.7)\end{array}$ & $\begin{array}{l}77.6- \\
88.6\end{array}$ & & $\begin{array}{l}72.1 \\
(18.3)\end{array}$ & $\begin{array}{l}61.1- \\
83.2\end{array}$ & & 0.049 \\
\hline \multicolumn{11}{|c|}{ Educational level } \\
\hline$\underset{+}{\text { High school }}$ & $\begin{array}{l}82.7 \\
(10.4)\end{array}$ & $\begin{array}{l}80.0- \\
85.5\end{array}$ & \multirow[t]{2}{*}{0.002} & $\begin{array}{l}86.3 \\
(6.1)\end{array}$ & $\begin{array}{l}83.5- \\
89.1\end{array}$ & \multirow[t]{2}{*}{0.002} & $\begin{array}{l}80.8 \\
(11.8)\end{array}$ & $\begin{array}{l}76.8- \\
84.8\end{array}$ & \multirow[t]{2}{*}{0.074} & 0.057 \\
\hline $\begin{array}{l}\text { High school } \\
-\end{array}$ & $\begin{array}{l}75.4 \\
(13.0)\end{array}$ & $\begin{array}{l}\text { 71.6- } \\
79.1\end{array}$ & & $\begin{array}{l}74.6 \\
(13.2)\end{array}$ & $\begin{array}{l}65.2- \\
84.1\end{array}$ & & $\begin{array}{l}75.6 \\
(13.1)\end{array}$ & $\begin{array}{l}71.3- \\
79.8\end{array}$ & & 0.842 \\
\hline \multicolumn{11}{|c|}{ Employment status } \\
\hline Employed & $\begin{array}{l}80.7 \\
(11.4)\end{array}$ & $\begin{array}{l}78.2- \\
83.3\end{array}$ & \multirow[t]{2}{*}{0.049} & $\begin{array}{l}84.8 \\
(7.1)\end{array}$ & $\begin{array}{l}81.7- \\
87.8\end{array}$ & \multirow[t]{2}{*}{0.01} & $\begin{array}{l}79.0 \\
(12.5)\end{array}$ & $\begin{array}{l}75.6- \\
82.3\end{array}$ & \multirow[t]{2}{*}{0.372} & 0.037 \\
\hline $\begin{array}{l}\text { Unemployed/ } \\
\text { unstable }\end{array}$ & $\begin{array}{l}75.4 \\
(13.6)\end{array}$ & $\begin{array}{l}70.0- \\
80.8\end{array}$ & & $\begin{array}{l}73.7 \\
(15.1)\end{array}$ & $\begin{array}{l}59.8- \\
87.7\end{array}$ & & $\begin{array}{l}76.0 \\
(13.4)\end{array}$ & $\begin{array}{l}69.7- \\
82.3\end{array}$ & & 0.718 \\
\hline \multicolumn{11}{|l|}{ CHD type } \\
\hline Simple & $\begin{array}{l}80.0 \\
(11.9)\end{array}$ & $\begin{array}{l}77.6- \\
82.5\end{array}$ & \multirow[t]{2}{*}{0.08} & $\begin{array}{l}82.9 \\
(9.7)\end{array}$ & $\begin{array}{l}79.1- \\
86.6\end{array}$ & \multirow[t]{2}{*}{0.053} & $\begin{array}{l}78.8 \\
(12.6)\end{array}$ & $\begin{array}{l}75.7- \\
81.9\end{array}$ & \multirow[t]{2}{*}{0.349} & 0.131 \\
\hline $\begin{array}{l}\text { Complex/ } \\
\text { PAH }\end{array}$ & $\begin{array}{l}74.3 \\
(12.9)\end{array}$ & $\begin{array}{l}67.4- \\
81.2\end{array}$ & & $\begin{array}{l}72.9 \\
(13.0)\end{array}$ & $\begin{array}{l}56.8- \\
89.0\end{array}$ & & $\begin{array}{l}74.9 \\
(13.5)\end{array}$ & $\begin{array}{l}65.9- \\
84.0\end{array}$ & & 0.786 \\
\hline \multicolumn{11}{|l|}{ CHD treatment } \\
\hline Repaired & $\begin{array}{l}79.6 \\
(11.7)\end{array}$ & $\begin{array}{l}77.1- \\
82.1\end{array}$ & \multirow[t]{2}{*}{0.501} & $\begin{array}{l}81.9 \\
(9.3)\end{array}$ & $\begin{array}{l}78.3- \\
85.5\end{array}$ & \multirow[t]{2}{*}{0.5} & $\begin{array}{l}78.5 \\
(12.6)\end{array}$ & $\begin{array}{l}75.2- \\
81.8\end{array}$ & \multirow[t]{2}{*}{0.772} & 0.206 \\
\hline $\begin{array}{l}\text { Unrepaired/ } \\
\text { palliative }\end{array}$ & $\begin{array}{l}77.7 \\
(13.8)\end{array}$ & $\begin{array}{l}71.7- \\
83.6\end{array}$ & & $\begin{array}{l}78.3 \\
(17.5)\end{array}$ & $\begin{array}{l}56.7- \\
100\end{array}$ & & $\begin{array}{l}77.5 \\
(13.3)\end{array}$ & $\begin{array}{l}70.9- \\
84.1\end{array}$ & & 0.905 \\
\hline
\end{tabular}

Table 4 EQ-VAS scores by subgroups in adults with congenital heart disease 


\begin{tabular}{|c|c|c|c|c|c|c|c|c|c|c|}
\hline & \multicolumn{3}{|l|}{ Total } & \multicolumn{3}{|l|}{ Men } & \multicolumn{3}{|c|}{ Women } & \multirow{2}{*}{$\begin{array}{l}p \text { - } \\
\text { value* }\end{array}$} \\
\hline & $\begin{array}{l}\text { Mean } \\
(S D)\end{array}$ & $95 \% \mathrm{Cl}$ & $\begin{array}{l}p- \\
\text { value }\end{array}$ & $\begin{array}{l}\text { Mean } \\
(S D)\end{array}$ & $95 \% \mathrm{Cl}$ & $\begin{array}{l}p- \\
\text { value }\end{array}$ & $\begin{array}{l}\text { Mean } \\
(S D)\end{array}$ & $95 \% \mathrm{Cl}$ & $\begin{array}{l}p- \\
\text { value }\end{array}$ & \\
\hline Total & $\begin{array}{l}66.3 \\
(12.5)\end{array}$ & $\begin{array}{l}63.9- \\
68.7\end{array}$ & & $\begin{array}{l}66.9 \\
(12.6)\end{array}$ & $\begin{array}{l}62.4- \\
71.4\end{array}$ & & $\begin{array}{l}66.1 \\
(12.6)\end{array}$ & $\begin{array}{l}63.2- \\
68.9\end{array}$ & & 0.754 \\
\hline \multicolumn{11}{|l|}{ Age groups } \\
\hline $16-30$ & $\begin{array}{l}69.9 \\
(10.8)\end{array}$ & $\begin{array}{l}66.4- \\
73.4\end{array}$ & \multirow[t]{2}{*}{0.024} & $\begin{array}{l}72.2 \\
(10.2)\end{array}$ & $\begin{array}{l}67.0- \\
77.1\end{array}$ & \multirow[t]{2}{*}{0.008} & $\begin{array}{l}68.1 \\
(11.2)\end{array}$ & $\begin{array}{l}63.0- \\
73.2\end{array}$ & \multirow[t]{2}{*}{0.385} & 0.228 \\
\hline $31+$ & $\begin{array}{l}64.3 \\
(13.1)\end{array}$ & $\begin{array}{l}61.2- \\
67.4\end{array}$ & & $\begin{array}{l}60.7 \\
(12.8)\end{array}$ & $\begin{array}{l}53.6- \\
67.8\end{array}$ & & $\begin{array}{l}65.3 \\
(13.1)\end{array}$ & $\begin{array}{l}61.7- \\
68.8\end{array}$ & & 0.259 \\
\hline \multicolumn{11}{|l|}{ Marital status } \\
\hline Married & $\begin{array}{l}67.0 \\
(11.2)\end{array}$ & $\begin{array}{l}64.4- \\
69.5\end{array}$ & \multirow[t]{2}{*}{0.376} & $\begin{array}{l}64.4 \\
(12.1)\end{array}$ & $\begin{array}{l}57.9- \\
70.8\end{array}$ & \multirow[t]{2}{*}{0.276} & $\begin{array}{l}67.6 \\
(11.0)\end{array}$ & $\begin{array}{l}64.8- \\
70.4\end{array}$ & \multirow[t]{2}{*}{0.016} & 0.306 \\
\hline Unmarried & $\begin{array}{l}64.6 \\
(15.5)\end{array}$ & $\begin{array}{l}58.8- \\
70.4\end{array}$ & & $\begin{array}{l}69.2 \\
(13.0)\end{array}$ & $\begin{array}{l}62.5- \\
75.9\end{array}$ & & $\begin{array}{l}58.5 \\
(16.9)\end{array}$ & $\begin{array}{l}48.3- \\
68.7\end{array}$ & & 0.058 \\
\hline \multicolumn{11}{|c|}{ Educational level } \\
\hline $\begin{array}{l}\text { High school } \\
+\end{array}$ & $\begin{array}{l}69.5 \\
(12.0)\end{array}$ & $\begin{array}{l}66.3- \\
72.7\end{array}$ & \multirow[t]{2}{*}{0.008} & $\begin{array}{l}71.9 \\
(9.1)\end{array}$ & $\begin{array}{l}67.6- \\
76.1\end{array}$ & \multirow[t]{2}{*}{0.015} & $\begin{array}{l}68.2 \\
(13.3)\end{array}$ & $\begin{array}{l}63.7- \\
72.7\end{array}$ & \multirow[t]{2}{*}{0.124} & 0.279 \\
\hline High school & $\begin{array}{l}63.2 \\
(11.9)\end{array}$ & $\begin{array}{l}59.7- \\
66.6\end{array}$ & & $\begin{array}{l}61.0 \\
(13.7)\end{array}$ & $\begin{array}{l}51.2- \\
70.8\end{array}$ & & $\begin{array}{l}63.7 \\
(11.6)\end{array}$ & $\begin{array}{l}60.0- \\
67.5\end{array}$ & & 0.526 \\
\hline \multicolumn{11}{|c|}{ Employment status } \\
\hline Employed & $\begin{array}{l}68.4 \\
(12.5)\end{array}$ & $\begin{array}{l}65.6- \\
71.2\end{array}$ & \multirow[t]{2}{*}{0.009} & $\begin{array}{l}71.1 \\
(9.6)\end{array}$ & $\begin{array}{l}67.1- \\
75.2\end{array}$ & \multirow[t]{2}{*}{0.009} & $\begin{array}{l}67.2 \\
(13.5)\end{array}$ & $\begin{array}{l}63.5- \\
70.8\end{array}$ & \multirow[t]{2}{*}{0.134} & 0.2 \\
\hline $\begin{array}{l}\text { Unemployed/ } \\
\text { unstable }\end{array}$ & $\begin{array}{l}61.3 \\
(10.0)\end{array}$ & $\begin{array}{l}57.4- \\
65.2\end{array}$ & & $\begin{array}{l}58.6 \\
(13.5)\end{array}$ & $\begin{array}{l}46.1- \\
71.0\end{array}$ & & $\begin{array}{l}62.3 \\
(8.7)\end{array}$ & $\begin{array}{l}58.2- \\
66.3\end{array}$ & & 0.411 \\
\hline \multicolumn{11}{|l|}{ CHD type } \\
\hline Simple & $\begin{array}{l}67.4 \\
(12.0)\end{array}$ & $\begin{array}{l}64.9- \\
69.9\end{array}$ & \multirow[t]{2}{*}{0.029} & $\begin{array}{l}68.8 \\
(12.0)\end{array}$ & $\begin{array}{l}64.2- \\
73.5\end{array}$ & \multirow[t]{2}{*}{0.034} & $\begin{array}{l}66.8 \\
(12.0)\end{array}$ & $\begin{array}{l}63.8- \\
69.8\end{array}$ & \multirow[t]{2}{*}{0.23} & 0.452 \\
\hline $\begin{array}{l}\text { Complex/ } \\
\text { PAH }\end{array}$ & $\begin{array}{l}60.0 \\
(14.1)\end{array}$ & $\begin{array}{l}52.5- \\
67.5\end{array}$ & & $\begin{array}{l}56.0 \\
(11.4)\end{array}$ & $\begin{array}{l}41.8- \\
70.2\end{array}$ & & $\begin{array}{l}61.8 \\
(15.4)\end{array}$ & $\begin{array}{l}51.5- \\
72.2\end{array}$ & & 0.465 \\
\hline \multicolumn{11}{|l|}{ CHD treatment } \\
\hline Repaired & $\begin{array}{l}66.9 \\
(12.6)\end{array}$ & $\begin{array}{l}64.2- \\
69.6\end{array}$ & \multirow[t]{2}{*}{0.352} & $\begin{array}{l}67.4 \\
(11.8)\end{array}$ & $\begin{array}{l}62.8- \\
72.0\end{array}$ & \multirow[t]{2}{*}{0.588} & $\begin{array}{l}66.6 \\
(13.1)\end{array}$ & $\begin{array}{l}63.2- \\
70.1\end{array}$ & \multirow[t]{2}{*}{0.47} & 0.797 \\
\hline $\begin{array}{l}\text { Unrepaired/ } \\
\text { palliative }\end{array}$ & $\begin{array}{l}64.1 \\
(12.3)\end{array}$ & $\begin{array}{l}58.8- \\
69.5\end{array}$ & & $\begin{array}{l}64.0 \\
(18.2)\end{array}$ & $\begin{array}{l}41.4- \\
86.6\end{array}$ & & $\begin{array}{l}64.2 \\
(10.9)\end{array}$ & $\begin{array}{l}58.8- \\
69.6\end{array}$ & & 0.979 \\
\hline
\end{tabular}

Table 5 Univariable and multivariable predictors of poor quality of life and health status in adults with congenital heart disease on logistic regression 


\begin{tabular}{|c|c|c|c|c|}
\hline Independent variables & B & S.E & p-value (Wald statistic) & OR $(95 \% \mathrm{Cl})$ \\
\hline \multicolumn{5}{|l|}{ Univariable logistic regression } \\
\hline \multicolumn{5}{|l|}{ Poor quality of life $(E Q-D S<65)$} \\
\hline Women & 0.964 & 0.799 & 0.228 & $2.62(0.55 ; 12.56)$ \\
\hline > 30 years old & 0.693 & 0.691 & 0.316 & $2.0(0.52 ; 7.75)$ \\
\hline Unmarried & 0.944 & 0.604 & 0.118 & $2.57(0.79 ; 8.4)$ \\
\hline Less than high school & 1.073 & 0.637 & 0.092 & $2.93(0.84 ; 10.19)$ \\
\hline Unemployed or unstable employment & 1.078 & 0.609 & 0.077 & $2.94(0.89 ; 9.7)$ \\
\hline Complex CHD or pulmonary artery hypertension & 1.575 & 0.654 & 0.016 & $4.83(1.34 ; 17.4)$ \\
\hline Unrepaired CHD or repaired palliation & 0.588 & 0.653 & 0.368 & $1.8(0.5 ; 6.5)$ \\
\hline \multicolumn{5}{|l|}{ Poor quality of life $(E Q-V A S<65)$} \\
\hline Women & 0.295 & 0.43 & 0.492 & $1.34(0.58 ; 3.12)$ \\
\hline$>30$ years old & 1.065 & 0.438 & 0.015 & $2.9(1.23 ; 6.84)$ \\
\hline Unmarried & 0.491 & 0.433 & 0.257 & $1.63(0.7 ; 3.81)$ \\
\hline Less than high school & 1.121 & 0.412 & 0.007 & $3.07(1.37 ; 6.88)$ \\
\hline Unemployed or unstable employment & 1.463 & 0.475 & 0.002 & $4.3(1.7 ; 10.95)$ \\
\hline Complex $\mathrm{CHD}$ or pulmonary artery hypertension & 1.016 & 0.559 & 0.069 & $2.76(0.92 ; 8.26)$ \\
\hline Unrepaired CHD or repaired palliation & 0.114 & 0.474 & 0.81 & $1.12(0.44 ; 2.84)$ \\
\hline \multicolumn{5}{|l|}{ Dissatisfaction with life $(S W L S<20)$} \\
\hline Women & 0.014 & 0.724 & 0.984 & $1.01(0.25 ; 4.19)$ \\
\hline$>30$ years old & -0.198 & 0.679 & 0.77 & $0.82(0.22 ; 3.1)$ \\
\hline Unmarried & 1.545 & 0.687 & 0.024 & $4.69(1.22 ; 18.01)$ \\
\hline Less than high school & 0.148 & 0.665 & 0.824 & $1.16(0.32 ; 4.27)$ \\
\hline Unemployed or unstable employment & 1.213 & 0.677 & 0.073 & $3.36(0.89 ; 12.69)$ \\
\hline \multicolumn{5}{|l|}{ Anxiety $(H A D S-A>10)$} \\
\hline Women & 1.504 & 0.779 & 0.054 & $4.5(0.98 ; 20.73)$ \\
\hline$>30$ years old & 0.606 & 0.562 & 0.281 & $1.83(0.61 ; 5.51)$ \\
\hline Unmarried & 0.74 & 0.521 & 0.155 & $2.1(0.76 ; 5.81)$ \\
\hline Less than high school & 0.984 & 0.519 & 0.058 & $2.68(0.97 ; 7.41)$ \\
\hline Unemployed or unstable employment & 1.171 & 0.525 & 0.026 & $3.23(1.15 ; 9.03)$ \\
\hline Complex $\mathrm{CHD}$ or pulmonary artery hypertension & 1.312 & 0.602 & 0.029 & $3.71(1.14 ; 12.08)$ \\
\hline Unrepaired CHD or repaired palliation & 0.643 & 0.561 & 0.252 & $1.9(0.63 ; 5.71)$ \\
\hline \multicolumn{5}{|l|}{ Depression $(H A D S-D>10)$} \\
\hline Women & 0.854 & 0.805 & 0.289 & $2.35(0.49 ; 11.37)$ \\
\hline
\end{tabular}




\begin{tabular}{|c|c|c|c|c|c|}
\hline Unmarried & 1.112 & 0.623 & \multicolumn{2}{|c|}{0.074} & $3.04(0.9 ; 10.32)$ \\
\hline Less than high school & 2.768 & 1.066 & \multicolumn{2}{|c|}{0.009} & $15.92(1.97 ; 128.52)$ \\
\hline Unemployed or unstable employment & 2.066 & 0.664 & \multicolumn{2}{|c|}{0.002} & $7.9(2.15 ; 29.01)$ \\
\hline Complex $\mathrm{CHD}$ or pulmonary artery hypertension & 0.767 & 0.73 & \multicolumn{2}{|c|}{0.293} & $2.15(0.52 ; 9.01)$ \\
\hline Unrepaired CHD or repaired palliation & 0.719 & 0.664 & \multicolumn{2}{|c|}{0.279} & $2.05(0.56 ; 7.54)$ \\
\hline \multicolumn{6}{|l|}{ Multivariable logistic repression } \\
\hline \multicolumn{6}{|l|}{ Poor quality of life $(E Q-D S<65)$} \\
\hline Complex $\mathrm{CHD}$ or pulmonary artery hypertension & 1.514 & \multicolumn{2}{|c|}{0.655} & 0.021 & $4.55(1.26 ; 16.4)$ \\
\hline Constant & 0.788 & \multicolumn{2}{|c|}{0.539} & 0.144 & \\
\hline \multicolumn{6}{|l|}{ Poor quality of life $(E Q-V A S<65)$} \\
\hline Unemployed or unstable employment & 1.426 & \multicolumn{2}{|c|}{0.475} & 0.003 & $4.16(1.64 ; 10.56)$ \\
\hline Constant & -0.693 & \multicolumn{2}{|c|}{0.408} & 0.09 & \\
\hline \multicolumn{6}{|l|}{ Dissatisfaction with life $(S W L S<20)$} \\
\hline Unmarried & 1.533 & \multicolumn{2}{|c|}{0.689} & 0.026 & $4.63(1.2 ; 17.86)$ \\
\hline Constant & 1.344 & \multicolumn{2}{|c|}{0.458} & 0.003 & \\
\hline \multicolumn{6}{|l|}{ Anxiety $(H A D S-A>10)$} \\
\hline Unemployed or unstable employment & 1.29 & \multicolumn{2}{|c|}{0.552} & 0.02 & $3.63(1.23 ; 10.72)$ \\
\hline Complex CHD or pulmonary artery hypertension & 1.43 & \multicolumn{2}{|c|}{0.636} & 0.024 & $4.19(1.2 ; 14.56)$ \\
\hline Constant & -0.616 & \multicolumn{2}{|c|}{0.701} & 0.379 & \\
\hline \multicolumn{6}{|l|}{ Depression (HADS-D > 10) } \\
\hline Unemployed or unstable employment & 2.039 & \multicolumn{2}{|c|}{0.664} & 0.002 & $7.68(2.09 ; 28.25)$ \\
\hline Constant & 0.865 & \multicolumn{2}{|c|}{0.421} & 0.04 & \\
\hline
\end{tabular}

\section{Figures}


Poor quality of life (EQ-DS < 65)

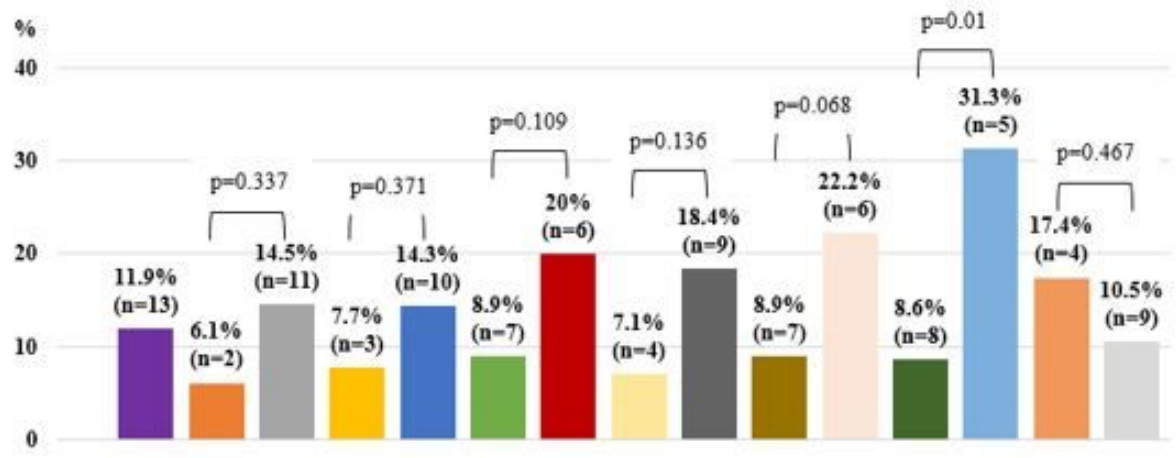

Poor quality of life (EQ-VAS < 65)

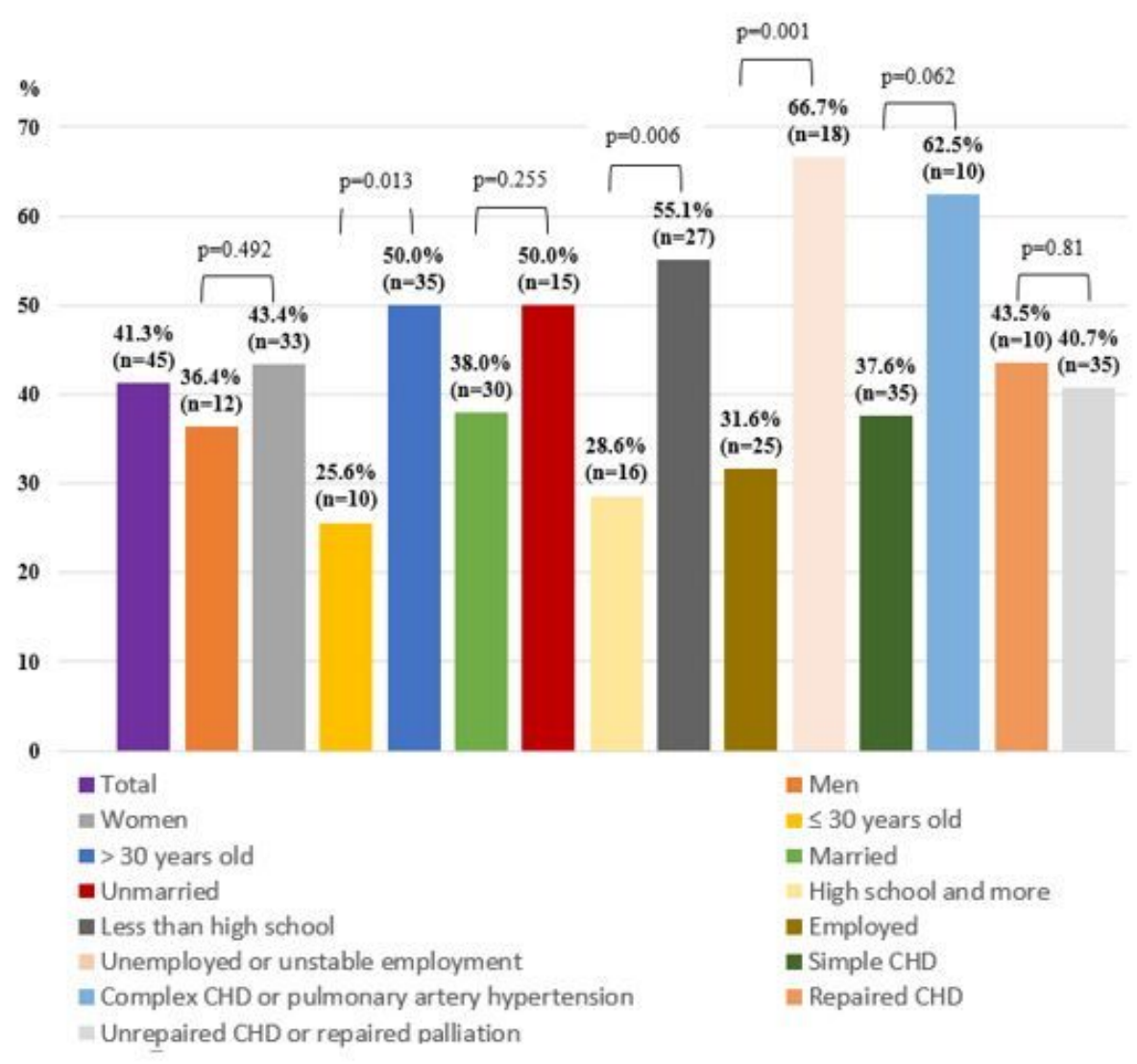

Figure 1

Poor quality of life by subgroups in adults with congenital heart disease 
Dissatisfaction with life (SWLS $<20$ )

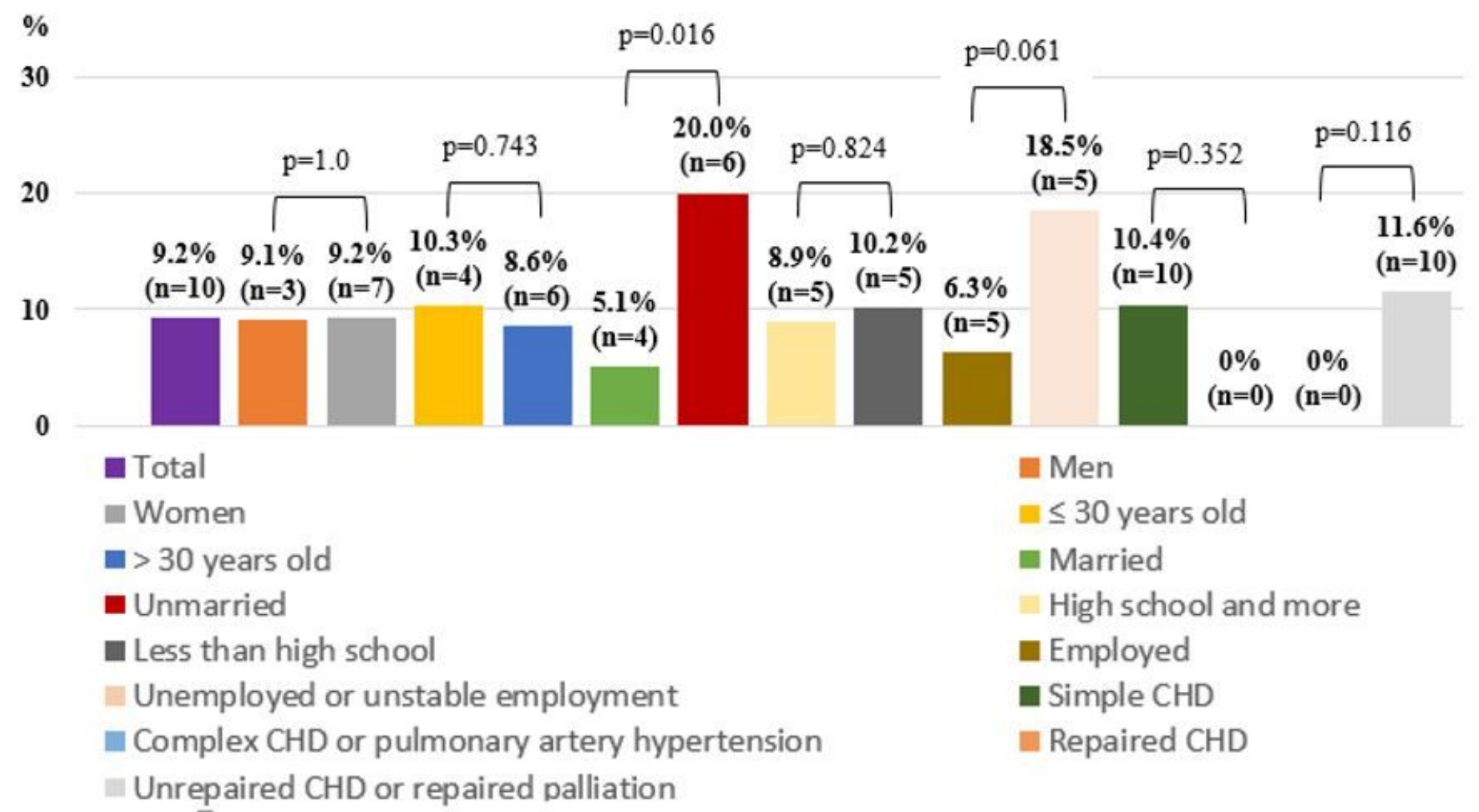

Figure 2

Dissatisfaction with life by subgroups in adults with congenital heart disease 
Anxiety (HADS-A > 10)

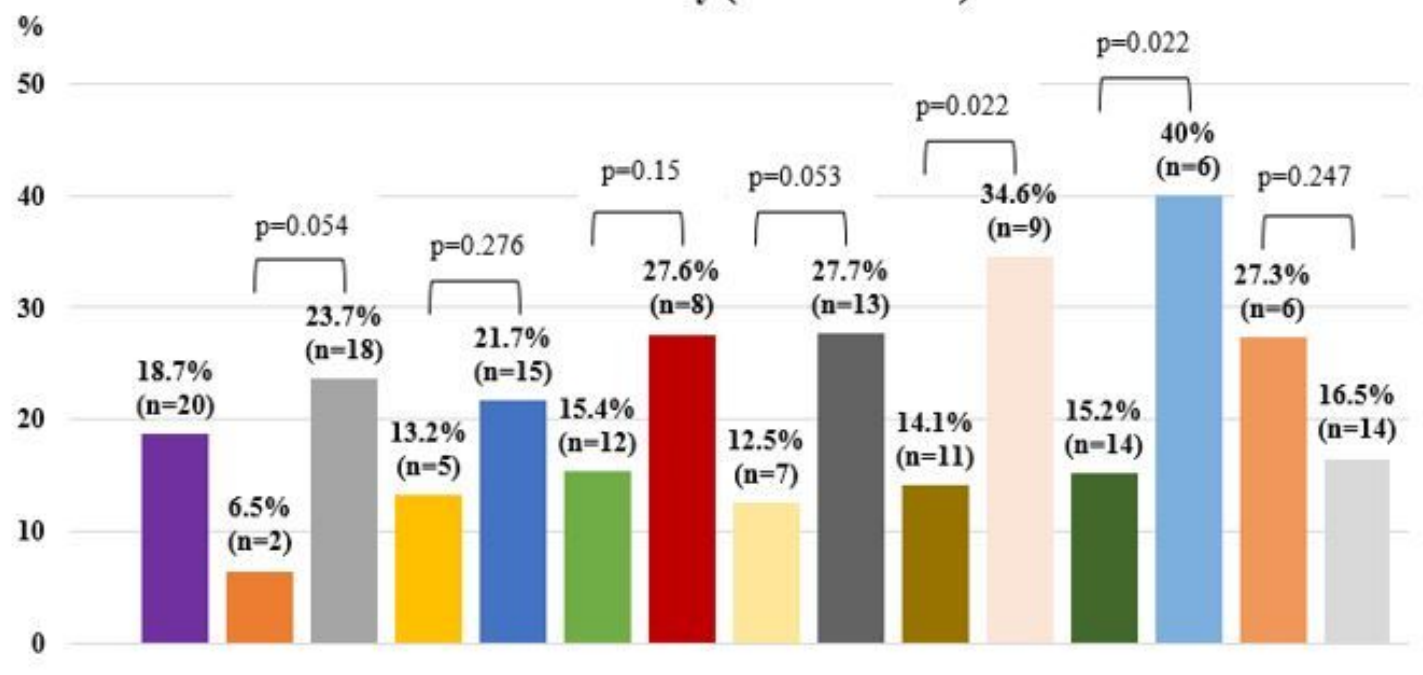

Depression (HADS-D > 10)

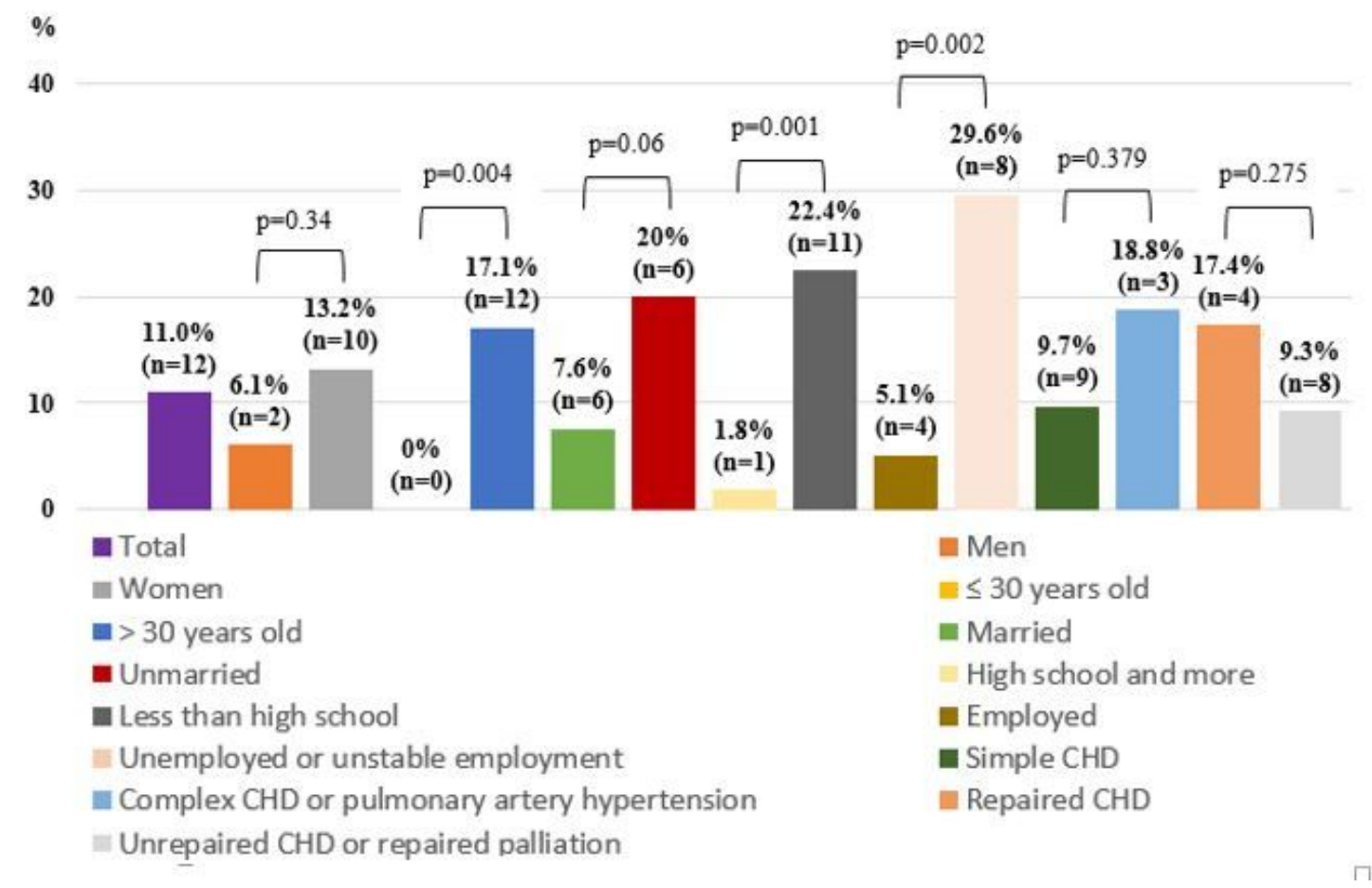

Figure 3

Symptoms of anxiety and depression by subgroups in adults with congenital heart disease

\section{Supplementary Files}

This is a list of supplementary files associated with this preprint. Click to download.

- Supplement1.docx 